\title{
OS TERRITÓRIOS FESTIVOS JUNINOS DE CAMPINA GRANDE (PB)
}

\author{
Jordania Alyne Santos Marques ${ }^{1}$ \\ Alessandro Dozena ${ }^{2}$
}

\begin{abstract}
Resumo: A relação entre espaço e cultura é versada nesse artigo com base nas práticas festivas juninas. Nele, busca-se analisar as festas juninas de Campina Grande (PB) enquanto uma manifestação cultural que condiciona múltiplas apropriações territoriais na cidade. A metodologia baseou-se na pesquisa bibliográfica e historiográfica, bem como no trabalho de campo, realizado por meio da observação participante, entrevistas, diálogos abertos, etnografia virtual e registros fotográficos. A partir das averiguações realizadas nas comemorações de bairros e no Parque do Povo, evidenciam-se as territorialidades protagonizadas pelos festeiros, pelo poder público e pela iniciativa privada. Possibilita-se assim a compreensão de que, mesmo em meio à lógica comercial e a espetacularização vigorante, as comemorações espontâneas nos bairros não deixam de existir, ao contrário, reinventam-se e recriam-se no período junino, a partir de disputas territoriais.
\end{abstract}

Palavras-chave: Festividades juninas. Territorialidades. Campina Grande.

\section{THE JUNE FESTIVAL TERRITORIES OF CAMPINA GRANDE (PB)}

\begin{abstract}
The relation between space and culture is studied in this article with basis in the june festivity practices. Thus, we search to analyse Campina Grande's june festival, as a cultural manifestation that conditions multiple territorial appropriations in the city. The methodology was based on bibliographical and historiographic research as well in the field work, through participant observation, interviews, open dialogues, virtual netnography/ethnography and photographic records. From the investigations performed, it is noticed the territorialities carried out by the festival people, public power and private initiative, in the commemorations of neighborhoods, in the central area of the city and in Parque do Povo. Enabling the understanding that even in the midst of commercial logic and spectacularization, the spontaneous celebrations in the neighborhoods do not cease to exist, on the contrary, they coexist, reinvent themselves and recreate from the territorial dispute.
\end{abstract}

Keywords: June festivities. Territorialities. Campina Grande.

\section{LOS TERRITORIOS FESTIVOS JUNINOS DE CAMPINA GRANDE (PB)}

Resumen: La relación entre espacio y cultura versa en este artículo en base a las prácticas festivas juninas. Así, buscamos analizar las fiestas juninas de Campina Grande, como una manifestación cultural que condiciona múltiples apropiaciones territoriales en la ciudad. La

\footnotetext{
${ }^{1}$ Mestra em Geografia pela Universidade Federal do Rio Grande do Norte-UFRN. É integrante do Grupo de Pesquisa Festas, identidades e territorialidades - FIT/CNPq. Email: jordania_gids@yahoo.com.br

${ }^{2}$ Professor Associado do Departamento de Geografia da Universidade Federal do Rio Grande do Norte - UFRN.

Email: sandozena@gmail.com
} 
metodología se basó en una búsqueda bibliográfica e historiográfica, así como en trabajo de campo realizado por medio de observación participante, entrevistas, diálogosabiertos, netnografía/etnografía virtual y registros fotográficos. A partir de las indagaciones realizadas, se evidencian las territorialidades protagonizadas por los asistentes de la fiesta, el poder público y la iniciativa privada, en las conmemoraciones barriales y en el Parque do Povo. Posibilitando la comprensión de que, así como en medio de la lógica comercial y la espectacularización vigorosa, lasconmemoraciones espontáneas en los barrios no dejan de existir, al contrario, coexisten, se reinventan y recrean a partir de la disputa territorial.

Palabras-clave: Festividads juninas. Territorialidades. Campina Grande.

\section{Introdução}

A relação entre a cidade e a festa não é algo recente, ela precede a sociedade capitalista (GRAVARI-BARBAS, 2011 apud FAINSTEIN, 1998). Na antiguidade, seu ensejo era incluir o homem na natureza sem causar desordem (KIM, 2011). É notório que os modos de organização e os locais de encontro variam de acordo com a sociedade e seus contextos histórico-culturais (MADOEUF, 2011) e que as festas são manifestações culturais que podem ter sua gênese relacionada ao período de plantação e colheita, matrimônios, nascimentos, mortes, festejos sacros e religiosos, eventos econômicos, sociais e políticos (ALBUQUERQUE JÚNIOR, 2013; CASTRO, 2012), passando por ressignificações, como ressalta Claval (1999), visto que a cultura não é algo cristalizado e/ou imutável.

Alguns estudiosos asseguram que as festas juninas são originadas na tradição de culto ao sol (CASTRO, 2012), outros pesquisadores as relacionam ao solstício de verão europeu, associando-as aos ciclos de produção agrícola, em que se rendia culto às divindades protetoras das colheitas (CASTRO, 2012; MORIGI, 2000). Assim sendo, no contexto europeu, a Igreja Católica passou a estabelecer os dias solenes visando modificar as festas, subdividindo-as em duas categorias: as celebrações do Senhor, destacando os acontecimentos da vida de Jesus e as datas rememorativas aos santos (CHIANCA, 2013; DEL PRIORE, 2000).

Utilizando-se do seu poder, a cada nova porção do território conquistado, a Igreja Católica introduzia "símbolos e representações relacionadas ao catolicismo (festas, procissões, missas) e a construção de símbolos para a identificação do território" (BONJARDIM; ALMEIDA, 2015, p. 117-118).

Assim sendo, "as festas eram o ponto alto da religião, momento que unia a sociedade para diversão, reunião das famílias e amigos" (BONJARDIM; ALMEIDA, 2015, p. 121). Ao mesmo tempo, elas indicavam a autoridade "do monarca ou do panteão católico" (DEL 
PRIORE, 2000, p. 17), determinando como as comemorações ocorreriam, cabendo aos negros e indígenas se submeterem às normas de comportamento impostas. Na oportunidade, eles eram catequizados, e desde essa época, nota-se um processo de segregação nas festas.

As irmandades e confrarias eram encarregadas de coordenar as festas religiosas, dentre elas, as procissões com estandarte do santo ovacionado, seguidas de arautos e soerguimento de mastros, com destaque para a solenidade de São Antônio, São João e São Pedro, nos dias 13, 24 e 29 de Junho, respectivamente. Assim sendo, com o passar dos anos, as famílias portuguesas, demais colonizadores, negros e indígenas foram adicionando elementos e símbolos às festas juninas (CHIANCA, 2013).

Após a Proclamação da República, alguns hábitos do período imperial passaram a ser negados por barões e burgueses (CHIANCA, 2013). Nesse cenário de rejeição, as festas juninas distanciam-se dos grandes centros, são introduzidas pelo mais pobres em diversas partes do país, intensificando hábitos antecedentes e, simultaneamente, agregando particularidades dos lugares (MORIGI, 2007).

Diante de um Nordeste imageticamente criado pelo regionalismo, ergue-se a festa junina constituída por vários elementos e símbolos: fogueira, balões, bandeirolas multicolores, celebrações religiosas católicas, adivinhações, compadrios, comidas típicas regionais, quadrilhas e forró (ALBUQUERQUE JÚNIOR, 2013; CHIANCA, 2013).

A partir da década de 1980, as festas juninas vêm se adequando e se instalando nas cidades pequenas, médias e em espaços metropolitanos, transformando-se em "eventos predominantemente profanos, mas que têm sua origem em elementos do sagrado, reinventados pela cultura popular e redesenhados no espaço urbano" (CASTRO, 2012, p. 51).

Sob esse panorama, Castro (2012), com base nas postulações de Deleuze e Guattari (1992; 1997;), alude que, atualmente, as festas no espaço urbano passam por um processo de “estriamento engendrado por 'máquinas' de cooptação e 'máquinas' de normatização e racionalização, tanto estatais quanto privadas, que conservaram alguns elementos relevantes das festas tradicionais e acrescentaram outros elementos e processos" (CASTRO, 2012, p. 44).

Em vista disso, algumas comemorações juninas são empregadas como táticas de geração de renda e para a eminência das cidades na dinâmica turística do Nordeste, a exemplo das cidades de porte médio do semiárido: Mossoró, no oeste do Rio Grande do Norte, exibida como "Cidade Junina do Brasil”, Campina Grande, na Paraíba, divulgada como “O maior São 
João do mundo", e Caruaru, em Pernambuco, propalada como "O melhor e maior São João do mundo" (BEZERRA, 2006; CASTRO, 2012).

Todavia, a atribuição mercadológica que envolve as festas juninas não remove ou dizima outras apropriações territoriais nas cidades, ao contrário, essas coexistem e estão justapostas (DOZENA, 2009; FERNANDES, 2003; MARQUES e BRANDÃO, 2015). Seja na particularidade da garagem da casa, na calçada da rua, nas igrejas, nos espaços públicos ou nas sedes dos eventos direcionadas ao turismo, procedem-se ocasiões de "encontro, reencontro, congraçamento, celebração e possibilidades de novas sociabilidades" (CASTRO, 2012, p. 310).

Nessa perspectiva, as festas juninas têm feito parte da dinâmica urbana de Campina Grande, desde a década de 1940, momento marcado pela constituição de suas áreas periféricas, em decorrência dos processos migratórios (EULÁLIO, 2014; LIMA, 2008). A partir de então, as confraternizações ocorrem de modo espontâneo, reafirmando as proximidades, os laços de afetividade e sociabilidade entre os amigos e familiares em suas residências e nas ruas. Posteriormente, as elites passaram a festejar em clubes e associações.

A partir da década de 1980, com o "Projeto Junino", tendo como carro chefe as quadrilhas juninas, a gestão municipal de Campina Grande passou a investir na centralização da comemoração em dois espaços: Açude Novo e Estação Velha. É nesse momento que Ronaldo Cunha Lima retoma a sua hegemonia política na cidade e constrói o Parque do Povo, em 1986, ampliando a espetacularização midiática e turística da festa junina na cidade (LIMA, 2008).

Atualmente, durante os trinta dias de festa junina, a cidade maquila-se e torna-se encantadora, havendo alterações na ornamentação das suas ruas, praças, estabelecimentos comerciais, prédios públicos e casas. Reveste-se com bandeirolas multicolores, luzes, fogueiras, candeeiros, fitas de cetim, balões, espigas de milho, chapéus, cestas de palha, imagens de Santo Antônio, São João e São Pedro, representações de casas de taipas/pau-apique (feitas de barro e madeira), bem como de tecidos de chita com estampas em xadrez e em cores fortes.

Além das modificações visuais, as festas juninas em Campina Grande apelam para os demais mecanismos perceptivos, por meio das sonoridades, com destaque para a combinação harmônica entre a sanfona, triângulo e zabumba, que desencadeia o forró. Os cheiros e sabores exalam, provenientes dos alimentos típicos da época, a exemplo da pamonha, mungunzá, canjica, pipoca, cuscuz, cocadas, paçoca, maçã do amor, tapiocas, queijos de 
coalho e manteiga, bolos de milho e pés de moleque. Todos esses elementos em conjunto acionam um imaginário rural e o pertencimento à comemoração.

O Parque do Povo se constitui como o núcleo sede da festividade. Durante as trinta noites, nele ocorrem as apresentações de quadrilhas juninas e grupos folclóricos, shows pirotécnicos e de artistas de renome nacional e regional, trios de forró pé-de-serra, concurso de bandas de forró e casamento coletivo, visando proporcionar divertimento à população local e, sobretudo, promover ganhos econômicos com a atividade turística.

A partir de uma recente Parceria Público-Privada (PPP), estabelecida entre a Prefeitura Municipal de Campina Grande e a empresa Aliança Comunicação e Cultura, montou-se uma estrutura composta por camarotes, roda gigante, bares, restaurantes, quiosques, palco principal, palhoças de forró, tenda com música eletrônica, área para vendedores ambulantes, estandes de patrocinadores, guaritas policiais, banheiros químicos, cidade cenográfica (com réplicas de uma fogueira gigante, de prédios históricos e da primeira rua da cidade), além de posto de saúde e de coleta de materiais recicláveis.

Simultaneamente a essa centralidade da festa, alguns espaços fixos e efêmeros localizados na área central da cidade e nas suas intermediações, passaram a dispor de uma programação no contraturno do Parque do Povo, como é o caso do Sítio São João, do Salão de Artesanato da Paraíba, do Parque da Criança, do Museu do Algodão, do Teatro Municipal Severino Cabral, da Vila do Artesão, do São João do Carneirinho, da Catedral Diocesana Nossa Senhora da Imaculada Conceição, do Cantinho da Benção, da Vila Junina e do Quadrilhando.

O Clube Campestre e as casas de espetáculos Vila Forró e Spazzio promovem, nos finais de semana e na véspera de São João, apresentações musicais com bandas de forró e sertanejo. A última casa citada organiza no primeiro final de semana de junho, o bloco namoradrilha, com trio elétrico tipicamente baiano, ao som de muito axé music, com o intuito de recordar o antigo carnaval fora de época de Campina Grande, a Miracande, saindo da Avenida Severino Bezerra Cabral, no bairro Catolé, defronte ao Shopping Partage, em direção ao Açude Velho, no centro da cidade. O percurso é de, aproximadamente, quatro quilômetros, e essa festa é considerada um símbolo de status, tendo em vista o alto custo do abadá.

Nos distritos de São José da Mata e Galante as festividades são realizadas no período diurno aos finais de semana, vésperas e dias dos Santos Antônio, João e Pedro, ficando ao encargo da gestão municipal em conjunto com a empresa Aliança. Contudo, Galante 
apresenta um maior destaque devido ao fato de receber a locomotiva Forrozeira, o Trem do Forró $^{3}$, que atrai um maior número de visitantes oriundos dos municípios circunvizinhos, de outras localidades da Paraíba, de outros estados do Nordeste e do Brasil.

Afastados das lógicas mercantilizadas vigorantes na festa junina midiática, outras festividades persistem nos bairros. Neles, ocorrem novenas, procissões e celebrações eucarísticas que rememoram a vida de Santo Antônio, São João e São Pedro. As quadrilhas tradicionais e estilizadas, forrós pé-de-serra, "paredões" de som, fogueiras e corrida de jegues igualmente compõem o cenário festivo e, em alguns casos, constatam-se camas elásticas e brincadeiras para as crianças. Nas ruas onde se realizam as comemorações é corriqueiro os moradores colocarem cadeiras em suas calçadas para acompanhar o movimento e aproveitar a ocasião para a venda de alimentos e bebidas.

Nessa perspectiva, a festa impulsiona a metamorfose da cidade, propicia uma dinâmica particular e fomenta múltiplas apropriações (GWIAZDZINSKI, 2011) as quais, em concordância com o pensamento de Morin (2005), vão se dando numa ordem e numa desordem. Logo, essa comemoração "obriga-nos a pensar as coisas no sentido da complementaridade e não da oposição, da complexidade e de maneira binária e setorial" (GWIAZDZINSKI, 2011, p. 349).

Tratando-se essa manifestação cultural por esse ângulo, passamos a refletir sobre a trama locacional concretizada por intermédio de ações e de objetos que estão dispostos fisicamente no espaço (GOMES, 2012), condicionando as dinâmicas que conformam as territorialidades. Em vista disso, através das comemorações, os festeiros demarcam, apropriam, percebem e vivenciam o território, gerando o que nomeamos de territorialidades festivas juninas.

O presente artigo se ancora no par dialógico território-territorialidades, em que o território é o resultado das "relações de dominação e/ou apropriação sociedade-espaço" (HAESBAERT, 2014, p. 58). Essas relações de poder são consideradas não apenas do ponto de vista das materialidades, mas também da sua função simbólica. Em outras palavras, "é o encontro entre uma área e os indivíduos em uma associação inalienável entre espaço (objetos) e uma estrutura de significados (sujeitos)" (PAULA, 2011, p. 120).

\footnotetext{
${ }^{3} \mathrm{O}$ trem é composto por sete vagões, todos animados por um trio de forró. Durante 1 h30 de percurso o passageiro pode dançar o forró "pé-de-serra" e contar com uma estrutura que dispõe de bares, banheiros, equipe médica e segurança. Ao chegar ao distrito de Galante, os passageiros podem usufruir de bares, restaurantes, shows e passeios locais. Às 15 horas, o trem retorna à cidade. Disponível em: <http://saojoaodecampina.com.br/locomotivaforrozeira>. Acesso em: 10/05/2017.
} 
Recorrendo às contribuições de Bonnemaison (2002), reiteramos que toda cultura se encarna em uma territorialidade, isto é, em uma dinâmica que se constitui em decorrência da criação e da apropriação do território, em um contexto em que as imaterialidades do espaço passam a adquirir uma significação efetiva (LIMA, 2016). Portanto, a noção de territorialidade situa-se entre fixação e mobilidade, sendo compreendida para além das noções biológicas e da macropolítica, sobressaindo-se "pela relação social e cultural que um grupo mantém com a trama de lugares e itinerários que constituem seu território" (BONNEMAISON, 2002, p. 287).

Em função das festividades juninas em Campina Grande, ocorrem interações entre os festeiros e o espaço que denotam muitas possibilidades de construção de significados e de valores subjetivos que são projetados e territorializados. No entanto, delimitamos como escala para esse trabalho as celebrações dos bairros e do Parque do Povo.

Essas comemorações acarretaram uma combinação entre entusiasmo e inquietação, manifestando-se através de alguns questionamentos: Onde se constituem os territórios festivos juninos na cidade de Campina Grande? Como esses territórios são apropriados? Quais vivências territoriais são estabelecidas? Partindo dessas indagações, formulamos o objetivo central desse artigo, que é compreender as apropriações territoriais mediadas pelas práticas sociais e representações subjetivas na festa junina da cidade de Campina Grande.

Para responder aos questionamentos formulados e cumprir com o objetivo proposto, buscamos o sustento metodológico na pesquisa qualitativa, considerando-a como uma das estratégias que favorece imergirmos na festa e entendermos os deslocamentos e os movimentos, compreendendo o espaço por intermédio das territorialidades.

Para tanto, foram elementares as fontes secundárias, as quais possibilitaram a construção de um campo discursivo sobre a festa junina de Campina Grande, especialmente no que concerne à comemoração no Parque do Povo, a partir de reportagens e notícias veiculadas pelos principais portais e jornais digitais da Paraíba e da cidade em estudo, assim como pelo site oficial do evento. Além disso, buscou-se entrar em contato com a gestão municipal em fevereiro de 2017, efetuando assim uma entrevista com o Secretário de Planejamento, que, na ocasião, já indicava o processo de terceirização da festa, bem como a saída do evento do Parque do Povo.

Nessa produção de informações, a pesquisa valeu-se das redes sociais digitais Facebook e WhatsApp, e por intermédio da Associação das Quadrilhas Juninas de Campina Grande (ASQUAJU-CG), foi possível identificar e estabelecer contato com as quadrilhas, um 
momento oportuno para tratarmos da organização de cada uma delas, dos principais festivais/concursos que elas participam, bem como dos locais de apresentação na cidade (essa última informação subsidiou a identificação das festividades de bairros). A União Campinense das Equipes Sociais (UCES) viabilizou os contatos telefônicos dos presidentes das Sociedades Amigos de Bairros (SABs) e, a partir disso, os indagamos sobre a existência de comemorações em suas localidades durante o período junino.

O Facebook foi utilizado a partir do grupo "Festa Junina de Campina Grande (PB)", sendo manejado como uma estratégia de pesquisa, no sentido da compreensão de como os participantes vivenciam as festividades. Para tanto, buscou-se embasamento na netnografia/etnografia virtual, que é uma técnica de observação das comunicações dos sujeitos no ciberespaço ${ }^{4}$ (CORRÊA; ROZADOS, 2017).

O trabalho de campo se configurou como uma permanente troca de saberes, sendo de suma relevância o interessar-se pelas conversas, pelas manifestações despretensiosas, e por tudo o que nos foi relatado, considerando-se que os sujeitos possuem saberes baseados no mundo conhecido e por eles significado. Com essa premissa, as questões vinculadas às materialidades foram transpassadas, sem, no entanto, desprender-se delas (HEIDRICH, 2016).

Todas as fases de levantamento das informações foram basilares para a efetivação das nossas viagens aos territórios festivos juninos, nos meses de Maio, Junho e Julho de 2017, ocasião em que a pesquisa valeu-se do uso do diário de campo, da observação participante, das entrevistas, dos diálogos abertos e do registro fotográfico e videográfico. Essas técnicas viabilizaram a imersão nas comemorações, em determinadas situações, mais proximamente, e em outras, mais afastados dos brincantes, na busca por compreender as apropriações, percepções e vivências estabelecidas nos territórios festivos juninos. A partir disso, a pesquisa foi realizada com a nossa participação nos eventos no Parque do Povo, nos bairros Bela Vista, Distrito Industrial, Jardim Quarenta, Dinamérica, Nova Brasília e Santo Antônio.

Para os registros, foi utilizado o diário/caderno de campo, a fim de descrever as observações, bem como o emprego da câmera fotográfica para efetuar os registros fotográficos e videográficos ${ }^{5}$, considerando-os não como meras ilustrações de um território

\footnotetext{
4"O ciberespaço é um espaço social em que as pessoas podem se encontrar sob os novos nomes de encontro e de personalização. O colapso das relações espaço-tempo e a evolução dos novos espaços sociais, sem espaço e sem lugar (Facebook, LinkedIn, Twiter, MySpace, etc.) desafiam a importância dos lugares geográficos a tal ponto que alguns acreditam que a geografia e o tempo não são mais fronteiras" (SANGUIN, 2014, p.14).

${ }^{5}$ Os vídeos não receberam nenhum tipo de edição, e todas as cenas foram captadas espontaneamente. Eles foram publicados no Youtube, com o intuito de proporcionar ao leitor um parâmetro sobre as diferentes formas de vivências estabelecidas nos territórios festivos, valendo-se não exclusivamente da linguagem escrita mas também
} 
festivo, mas como "uma narrativa que tem sentido simbólico, cultural e imagético" (MELO, 2008, p. 81). Por fim, optou-se pelas entrevistas, por se tratar de uma técnica valiosa para se usar na pesquisa com pessoas e grupos sociais e suas geografias (HEIDRICH, 2016). Assim, empregou-se a entrevista não-diretiva, em que o entrevistado tem autonomia para exteriorizar suas opiniões e sentimentos, cabendo ao entrevistador instigar e direcionar o depoente a proferir sobre determinado conteúdo, sem, no entanto, pressioná-lo a responder (ÁLVAREZ, 2011).

O presente artigo é composto por três subcapítulos. No primeiro, "Adentrando nos territórios festivos juninos de Campina Grande", a ênfase é direcionada para a constituição dos territórios festivos na cidade. No segundo, "As festividades nos bairros de Campina Grande", são ressaltadas as comemorações ocorridas nas igrejas, residências e ruas, pontuando-as como locais de sociabilidade. E no terceiro, "Território espetacular: O Parque do Povo", discute-se sobre o caráter turístico-mercadológico dessa comemoração nesse local, assim como são salientados os embates e as territorialidades que proporcionam movimento ao território festivo.

\section{Adentrando nos territórios festivos juninos de Campina Grande}

Ao adentrar nos territórios festivos juninos de Campina Grande, é possível se deparar com territórios que se distinguem "de acordo com aqueles que os constroem, sejam eles indivíduos, grupos sociais/culturais, o Estado, empresas, instituições como a Igreja, etc" (HAESBAERT, 2014, p. 59). Nas festas juninas de Campina Grande, os festeiros têm o ensejo principal de se divertirem nas festas espetacularizadas: na festividade pública do Parque do Povo ou nas casas privadas de espetáculos. Todavia, há de se concordar que as comemorações não se restringem aos fins mercadológicos e turísticos, visto que nelas encontramos celebrações espontâneas realizadas na intimidade dos lares, em determinadas ruas da cidade, praças e igrejas.

O Mapa 1 permite observar que durante as comemorações juninas, emergem lugares simbólicos "construídos tanto por seus moradores quanto pelos interesses de pessoas externas ao lugar, seja a população em geral ou um específico segmento dela, sejam grupos empresariais ou o Estado" (CORRÊA, 2012, p. 140).

dos recursos visuais e auditivos, levando-os ao contato com as experiências festivas. Os vídeos estão disponíveis em: https://www.youtube.com/channel/UC6U_cWjzryCWvzafu50beQg/videos. Acesso em: 25/09/2018. 


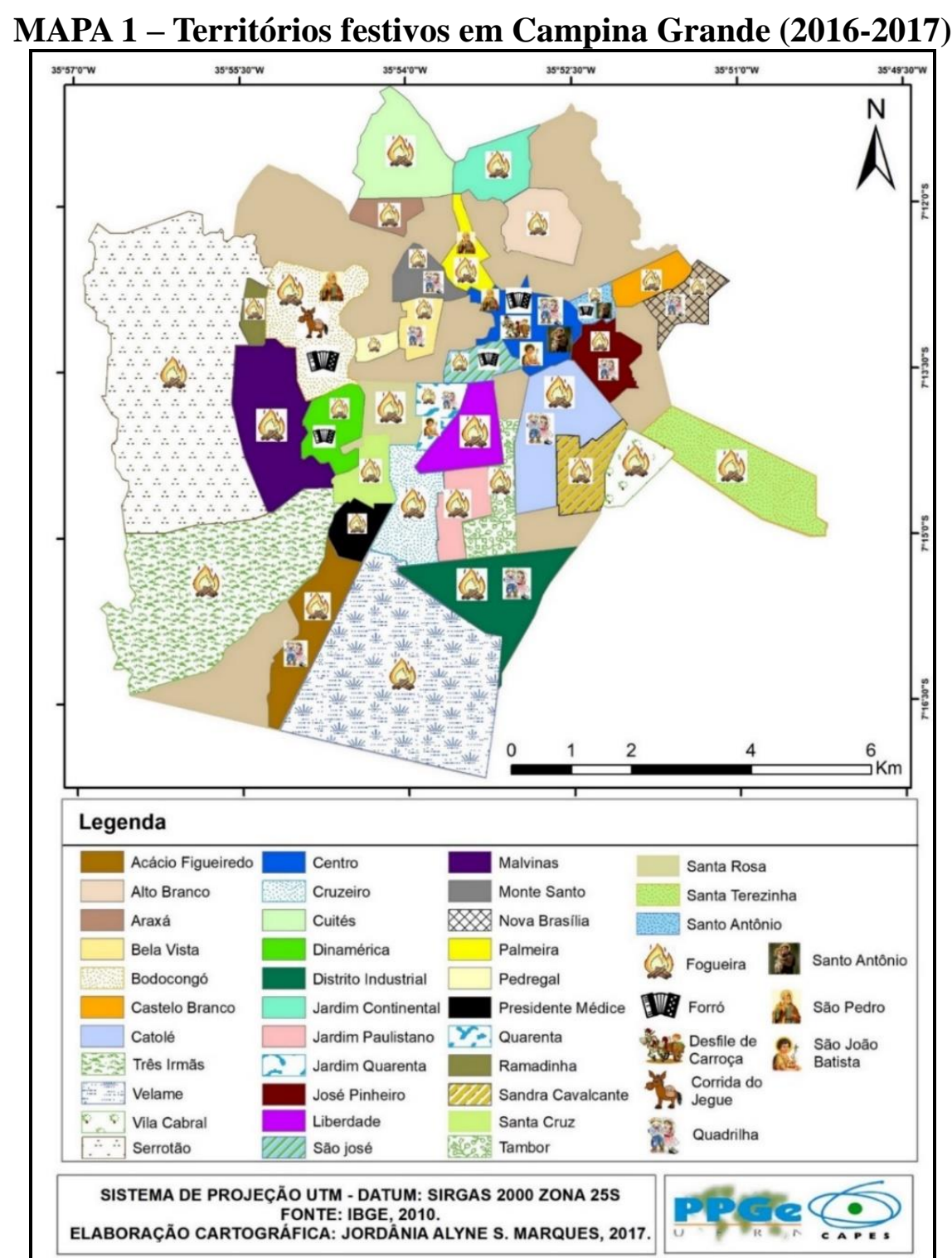

Fonte: MARQUES (2018).

Os 36 bairros mapeados trazem consigo elementos e símbolos da festividade em áreas periféricas. É notória a significativa quantidade de fogueiras, a presença da sanfona como símbolo da sonoridade predominante, o forró como dança e gênero musical, além das quadrilhas juninas. Igualmente, são significativas as comunidades que têm os santos juninos como padroeiros de seus bairros. Em menor expressão, mencionamos a ocorrência das corridas de jegue e do desfile de carroças.

\section{As festividades nos bairros de Campina Grande}

Nos bairros de Campina Grande, no período junino, surgem comemorações nas igrejas católicas, entre familiares e amigos que se reúnem em suas residências para celebrar esse momento nas ruas, configurando-se "locais de sociabilidade onde se expressam experiências 
não remuneradas, fundamentadas no encontro comum que ali se dá e que torna esses lugares um ambiente comum a todos" (DOZENA, 2012, p. 219).

Em conversa com os moradores dos bairros, é comum a atribuição do declínio das festas nas residências pela sua turistificação, pois os mais jovens preferem se deslocar para o Parque do Povo e casas de espetáculos. A crescente violência urbana também foi mencionada como desestimuladora do permanecer em frente às casas e do celebrar o ciclo junino. Os mais velhos salientaram que a pavimentação asfáltica das ruas e as leis ambientais urbanas causam um descompasso na natureza lúdica das comemorações juninas. Alguns entrevistados relataram o sentimento de frustração em não acender a sua fogueira.

Nesse contexto, as intervenções realizadas no espaço urbano pela gestão pública municipal, assim como a violência urbana, a falta de apoio do poder público e o desânimo por parte da juventude, representam rupturas nas práticas culturais de determinadas pessoas. Todavia, em alguns bairros, essas práticas relacionadas ao imaginário social local continuam ocorrendo. Passaremos a descrevê-las na sequência.

O "Arraial da Volta" ocorreu na rua Sargento Hermes Ferreira Ramos, no bairro Bela Vista, que estava enfeitado de bandeirolas. Por volta das 19 horas, acontecia o culto dominical da Igreja Assembleia de Deus. Por esse motivo, os organizadores planejaram o início da festividade para as 20 horas. $\mathrm{O}$ carro de som, a iluminação e o isolamento da rua ficaram a cargo da Prefeitura Municipal de Campina Grande. Já a decoração e os lanches para as quadrilhas foram patrocinados pelos membros da sociedade de bairro local.

A festividade desse bairro se detém às apresentações das quadrilhas juninas. Assim, a comunidade organizou uma quadrilha infantil denominada "Junina Molekada", que, ao entrar no arraial, trouxe imagens dos santos Antônio, João e Pedro, bem como uma cruz, estabelecendo relações entre a festa junina e os santos católicos. Iniciando-se a dança, foram soltados fogos de artifícios, confetes, bombinhas e chuveirinhos, e os passos executados foram os tradicionais e alguns outros mais elaborados, já incorporados nas quadrilhas estilizadas 6.

Na sequência, ocorreu a encenação do casamento matuto, com decoração e cenário ao fundo, além de música sertaneja universitária após as bênçãos do padre. Enquanto tudo isso acontecia, os pais, familiares e festeiros assistiam e cantavam as músicas bem empolgados. As crianças receberam como recompensa por suas apresentações um lanche na casa de uma das líderes da comunidade.

\footnotetext{
${ }^{6}$ Registro videográfico. Disponível em: 〈https://www.youtube.com/watch?v=z8OQrWEXjxM>. Acesso em: $10 / 09 / 2017$
} 
Também houve as apresentações das quadrilhas juninas "Escorrega Mais Num Caí" e "Arraial em Paris". Muitos presentes reclamaram do fato de as quadrilhas não estarem com o conjunto total das apresentações, pois era notório o pequeno número de dançarinos e a ausência da cenografia. No momento dessas apresentações, começou a chover, mas mesmo assim, grande parte do público não foi embora. Alguns moradores aproveitaram para vender cachorro quente, salgados, milho cozido e assado.

Encontrar-se na véspera de São João, no dia 24 de Junho, é comum na família Caluête, em Bodocongó. Os familiares vêm de outras ruas do bairro e da cidade, o momento é propício para realizar orações em agradecimento pelas bênçãos concebidas nos seis primeiros meses do ano, para saborear comidas regionais e churrasco.

No dia 30 de Junho de 2017, as sociedades de amigos dos bairros Ramadinha e Bodocongó organizaram uma festividade na rua Florípedes Coutinho, em Bodocongó. Os participantes reuniram-se com a finalidade de ornamentar a rua com bandeirolas, assim como ratearam o aluguel da sonorização que animou o arraial para a apresentação da quadrilha. Os componentes eram sócios das Sociedade Amigos dos Bairros - SAB. Alguns populares aproveitaram a oportunidade para vender churrasco, bebidas e doces.

Ainda no mesmo bairro, desde 2010, realiza-se a "Corrida de Jegue" na comunidade São Januário. De acordo com o seu idealizador, o propósito do evento é estimular o resgate da cultura nordestina e propiciar um dia de lazer para os moradores da localidade, campinenses e visitantes das cidades circunvizinhas. Trata-se de um momento de conscientização sobre os cuidados necessários com os animais, tais como: alimentação, vacinação e o não deixar próximo às vias de circulação a fim de se evitar acidentes.

Para participar da corrida os interessados não necessitam pagar nenhum tipo de taxa de inscrição, pois “os criadores de jegue são pessoas carentes, e em muitos casos, o animal é usado como instrumento de trabalho" (José, entrevista concedida em 3 de Julho de 2017). Diante disso, os moradores e comerciantes da localidade fazem doações de prêmios para as cinco primeiras colocações (as três primeiras recebem a premiação em forma de dinheiro, enquanto as duas últimas ganham sacos de milho). Para isso, são realizadas sequências de baterias de corridas, classificando-se os três primeiros colocados. Os perdedores disputam as duas últimas vagas para a grande final.

Em 2016 aconteceu a última edição da corrida. Com a ausência da sonorização e do trio de forró pé-de-serra, disponibilizados anteriormente pela prefeitura, acabou-se inviabilizando a concretização do evento. Vale mencionar que a organização havia 
encaminhado o ofício à coordenadoria de eventos desde o mês de abril, que havia dado aval quanto ao apoio. Apesar disso, a demanda solicitada não obteve êxito, evidenciando-se a difícil face da terceirização da organização da festa na cidade de Campina Grande.

Na noite de São João, a rua Manoel Alves de Nascimento, no bairro Distrito Industrial, estava bem iluminada e enfeitada de bandeirolas. A SAB se encarregou de conseguir carro de som e iluminação com a prefeitura de Campina Grande. O envolvimento da comunidade com a festividade foi bem tímido, ela colaborou com a organização da decoração da rua e com a doação de alimentos para o lanche dos componentes da quadrilha "Expressão Junina" do bairro Catingueira. Para o deslocamento dos integrantes da quadrilha foi primordial o apoio do presidente da empresa de ônibus Cruzeiro. Alguns moradores aproveitaram o momento para vender milho, espetinhos, batata frita e cervejas em frente as suas residências.

No bairro Dinamérica, O "Pé de Serra no Quintal” foi criado para difundir a cultura nordestina. "Aqui só toca forró autêntico e música popular brasileira, aqui não tem essa história de funk e de pancadão não" (Eduardo, entrevista concedida em 2 de Julho de 2017). Nesse local, a prática dançante não se limita ao período junino, ocorrendo nos fundos da casa do organizador todas as quartas-feiras e domingos. Para acesso a este local, paga-se a quantia de cinco reais. Ao adentrar, logo se depara com muitas bandeirolas e balões, bar comercializando bebidas alcoólicas e não alcoólicas e um público, em sua maioria, formado por adultos bem animados ${ }^{7}$.

Ao conversar com uma senhora, ela relatou que costuma frequentar o Parque do Povo, mas que possuía uma maior identificação com o fundo de quintal: "gosto mais daqui, é mais amigável, só tem gente de família e não tem a violência que se tem lá (Flávia, entrevista concedida em 2 de Julho de 2017). A festeira atribui a esse espaço uma sensação de segurança e intimidade entre os seus frequentadores.

No dia 16 de Junho de 2017, a praça Severina Elza de Araújo, localizada na rua Papa João Paulo I, transformou-se no arraial do bairro Nova Brasília. Há 21 anos, a SAB e os clubes de mães e moradores organizam esse dia de festividade junina, tendo como principal atração a quadrilha junina. No entanto, gradualmente, vem diminuindo o interesse da comunidade em participar desses momentos. De acordo com a organizadora do arraial, "além da questão financeira, há a diminuição no incentivo às quadrilhas tradicionais" (Flávia, entrevista concedida em 16 de Junho de 2017). A sonorização e iluminação da praça ficou a

\footnotetext{
${ }^{7}$ Registro videográfico disponível em: 〈https://www.youtube.com/watch?v=vbhjeoZJMSM\&t=18s >. Acesso em: $10 / 09 / 2017$.
} 
cargo da prefeitura e de um deputado estadual. Já a comunidade se responsabilizou pelo lanche das crianças que se apresentaram nas quadrilhas.

Ao final da tarde, com poucas pessoas no local, as crianças da quadrilha junina da Fundação Padre Ibiapina, do bairro José Pinheiro, brincavam nos equipamentos da academia de saúde popular. A duração da festividade foi bem curta, primeiro ocorreu o sorteio de uma rifa de uma cesta básica beneficente ao clube de mães, na sequência, as crianças se apresentaram $^{8}$. Assim que a quadrilha se despediu, as poucas pessoas presentes saíram rapidamente, ficando a praça quase deserta.

A paróquia de Santo Antônio celebra a solenidade de seu padroeiro desde 1942. Em 2017, foram treze noites de celebrações eucarísticas, adoração do Santíssimo Sacramento e procissão entre 1 e 13 de Junho, com a participação das comunidades, movimentos pastorais que integram a paróquia, além de padres e fiéis de outras paróquias. Antes de iniciar a missa, em uma conversa com uma senhora de 75 anos, ela nos relatou a sua devoção ao santo e às práticas festivas em seu bairro:

Ele representa muito para mim, pois era um santo humilde, pobre, dava tudo que possuía para os mais carentes. Desde nova, em frente à minha casa, sempre fazíamos fogueira para todos os santos do mês, porém, hoje não fazemos isso por causa da violência e porque minha rua é asfaltada (Irene, entrevista concedida em 12 de junho de 2017).

No dia 12 de Junho, na véspera de Santo Antônio, a Igreja Matriz estava adornada de rosas e com a presença de muitos fiéis. Após a celebração eucarística, na rua Josino Agra, houve a quermesse com a venda de salgados, churrasquinho, creme de galinha, pamonha, canjica, cachorro-quente, tapioca, caldos e refrigerantes, sendo vedada a venda e o consumo de bebidas alcoólicas. Para animar os festeiros, havia uma banda de forró, assim como camas elásticas para as crianças brincarem ${ }^{9}$. Este momento também foi por nós considerado um ponto alto da festividade:

A Festa de Santo Antônio é um momento de grande alegria, pois além de podermos expressar nossa fé através das atividades religiosas, também podemos participar de eventos sociais que favorecem nossa comunhão fraternal com os nossos irmãos em Cristo, além da valorizarmos a cultura cristã (Pedro, entrevista concedida em 13 de junho de 2017).

\footnotetext{
${ }^{8}$ Registro videográfico disponível em: https://www.youtube.com/watch?v=WdwEwD7-YO0\&t=71s, acesso em: 10/09/2017.

9 Registro videográfico disponível em: https://www.youtube.com/watch?v=XF0wRYGDSkw, acesso em: $10 / 09 / 2017$.
} 
Desde 1992, no bairro Jardim Quarenta, a comunidade São João Batista realiza a festividade em louvor ao santo. Em 2017 foram realizadas sete noites de celebrações, entre os dias 18 e 24 Junho, com a participação das comunidades e movimentos pastorais da paróquia de Santa Rosa Mística, como indica uma das coordenadoras da festa:

Todos os anos sentamos e planejamos com muito carinho a nossa festa, porém a participação ainda é tímida, pois de certa maneira concorremos com as outras tradições culturais aqui de Campina Grande. Daí termos um número pequeno de pessoas em nossas celebrações (Luiza, entrevista concedida em 24 de junho de 2017).

Na noite de São João, a pequena capela estava decorada com bandeiras multicores e balões. Algumas pessoas estavam vestidas com blusas xadrez, chapéus e fitas coloridas no cabelo. Na missa, evidenciou-se a solenidade da natividade de São João Batista, o precursor, aquele que teve a missão de ser o arauto de Cristo. Após a celebração eucarística, deu-se início à quermesse no pequeno pátio anexo à capela, com a venda de tortas, cachorro-quente, mugunzá, escondidinho de macaxeira com carne de sol e refrigerantes.

Ainda no mesmo local, foram desenvolvidas algumas brincadeiras: pescaria e jogos de argola para as crianças, as quais se divertiam muito ao pegar os peixes e colocar as argolas nas varetas. Tais crianças se enchiam de sorrisos ao receber uma premiação em forma de doces. O momento também foi oportuno para alguns adultos brincarem e reativarem suas memórias das festas com seus filhos e amigos. Na lateral da capela, na rua João Nunes Figueiredo, crianças brincavam na cama elástica e soltavam chuveirinhos (fogos de artifício).

No entanto, as atenções estavam mais voltadas para as apresentações das crianças da pré-catequese. Os meninos com camisas xadrez, calça remendada e chapéu de palha, as meninas com vestidos de chita e arranjos no cabelo, dançavam ao som da música "Farinhada", de Luiz Gonzaga ${ }^{10}$. Finalizando a noite, os casais da paróquia puxaram uma quadrilha improvisada com os presentes na comemoração.

\section{Território espetacular: o parque do povo}

Em Campina Grande, alguns críticos, há anos, questionam os altos investimentos públicos envolvidos na festividade junina, haja vista a necessidade de melhorias na educação,

10 Registro videográfico disponível em: https://www.youtube.com/watch?v=X6Cz_IovaE0 , acesso em 10/09/2017. 
saúde e serviços urbanos básicos. Sob essa ótica, as tensões nas festividades juninas no Parque do Povo, em 2017, começaram desde o anúncio da terceirização da mesma, agravando-se com a divulgação da programação do palco principal.

A presença de artistas sertanejos, de forró eletrônico, axé music e funk dividiu opiniões. Alguns festeiros elogiaram as atrações, em contrapartida, outros se manifestaram combatendo veementemente os shows, em consonância com os emotions atribuídos aos nomes dos artistas (Figura 1).

\section{Figura 1 - Manifestação com relação a Programação do Palco Principal}

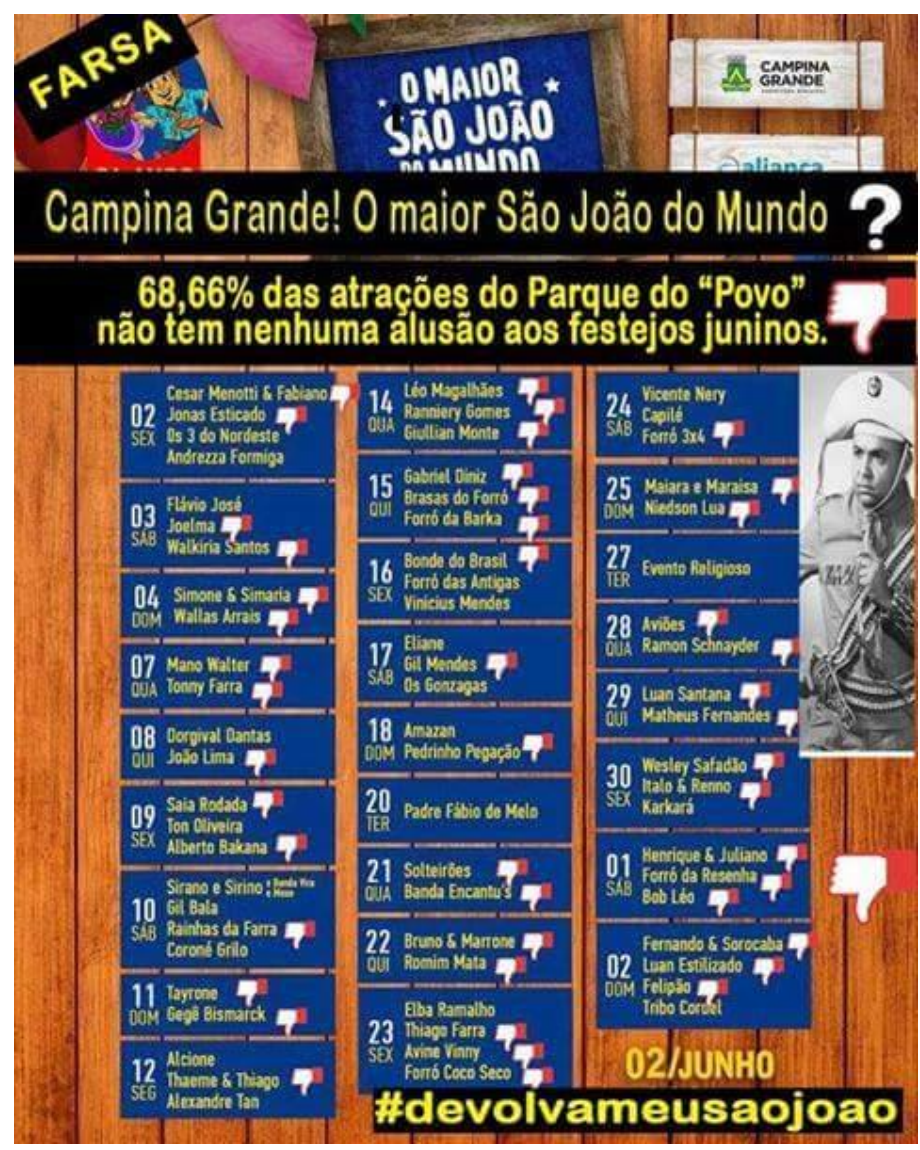

FONTE: Autor desconhecido (2017). Disponibilizado por um membro do Grupo do Facebook "Festas Juninas de Campina Grande".

Ao utilizarem a \#devolvameusaojoao nas redes sociais, artistas nordestinos e festeiros argumentavam a perda de autenticidade da comemoração: "a curto prazo a terceirização pode até trazer ganhos econômicos, porém, a longo prazo vai diminuir a identidade nordestina" (Paulo, entrevista concedida em 10 de junho de 2017).

Tendo como arcabouço as postulações de Bezerra (2006), Castro (2012) e Lima (2008), constatamos que a festa junina do Parque do Povo transformou-se em um megaevento 
que acarreta enormes ganhos econômicos para empresários e comerciantes, além de ser usada midiaticamente na promoção da política partidária. O São João de Campina Grande, organizado desde 2016 pela empresa Aliança (fato que se prolongará até 2036), foi aprovado pela Câmara Municipal de Campina Grande e busca atrair empresas para o patrocínio da festa junina, sendo que em contrapartida suas marcas ganham visibilidade em telões, televisão, redes sociais digitais, bem como ocorre a venda exclusiva no interior do local festivo.

É válido salientar que os embates entre a empresa e os vendedores do Parque do Povo foram intensos, pois a Aliança aumentou consideravelmente os valores dos aluguéis de quiosques, bares e restaurantes, bem como das bebidas e do gelo, que só podiam ser comprados no depósito da patrocinadora Ambev, que apresentava os valores acima do mercado, conforme os relatos dos comerciantes entrevistados.

Considerando-se a lógica mercadológica em que a festividade está envolvida, o Mapa possibilita visualizar o layout do Parque do Povo em 2017. Nesse ano a festividade teve início no dia 2 de Junho de $2017^{11}$ e se encerrou em 2 de Julho de 2017.

${ }^{11}$ Registro videográfico disponível em: https://www.youtube.com/watch?v=M1zyJ1W3uD8\&t=101s, acesso em: 10/09/2017. 


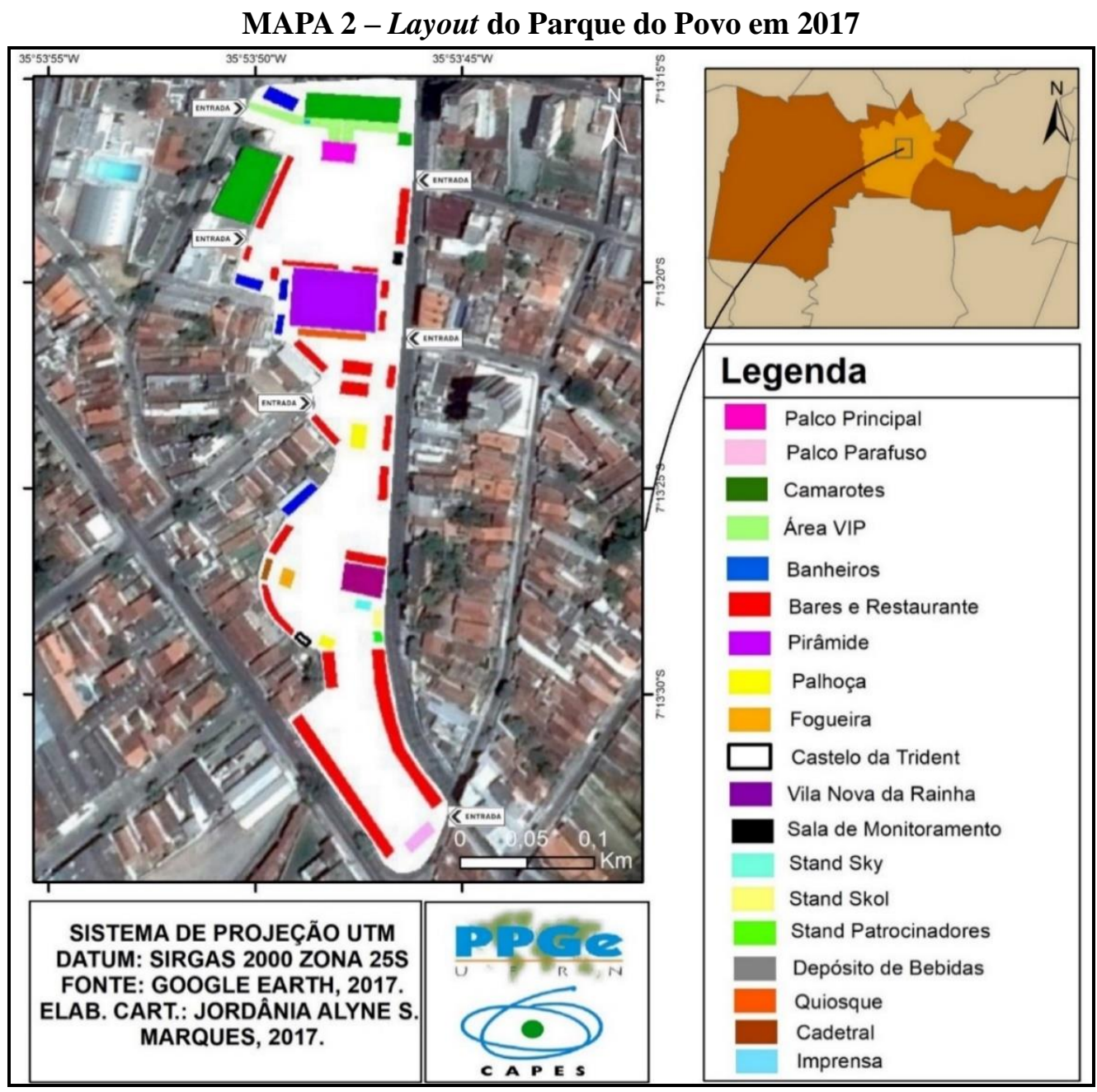

FONTE: MARQUES (2018).

Nota-se uma racionalidade das formas rígidas fixas e efêmeras (CASTRO, 2012), configurando um desenho e/ou uma forma da festa, contendo palco principal e secundário, camarotes, pirâmide, quiosques, bares, restaurantes, palhoças de forró pé-de-serra, cidade cenográfica, banheiros e stand de patrocinadores.

Percebemos no Parque do Povo uma segmentação do ponto de vista socioeconômico e de orientação sexual que se reverbera no território e produz territorialidades, nas proximidades do palco principal. Inclusive, os próprios festeiros percebem isso e as delimitam (Figura 2). É claro o aumento da extensão privada em frente ao palco principal por meio dos camarotes e Área Vip, além dos maiores banheiros fixos do local estarem situados nessa área. 


\section{FIGURA 2 - Territorialidades do Palco Principal}

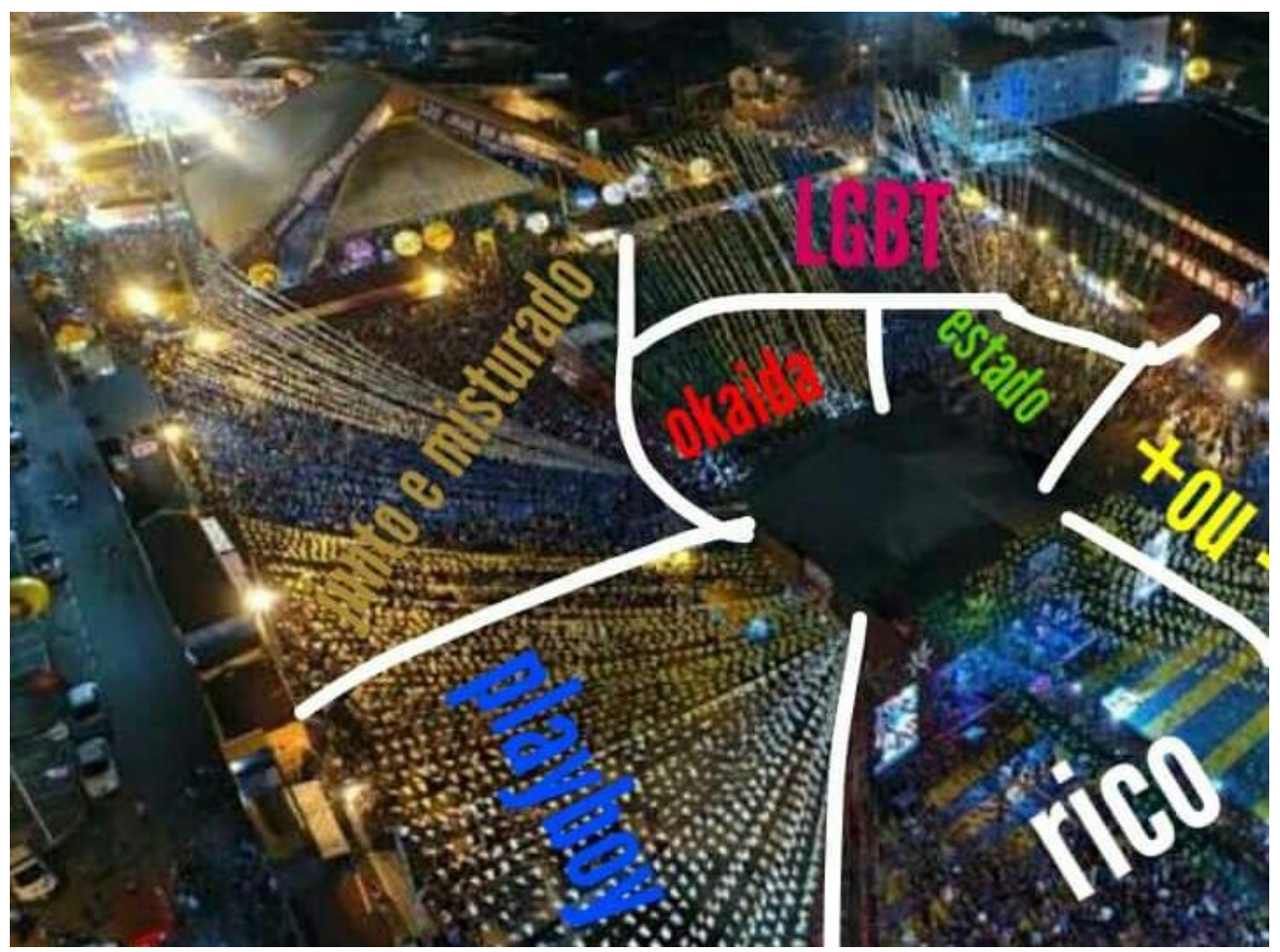

FONTE: Autor desconhecido (2017). Disponibilizado por um membro do Grupo do Facebook "Festas Juninas de Campina Grande".

Sobre as territorialidades LGBT, elas se manifestam de modo especial no Bar do Tenebra, considerado por seus frequentadores como um local democrático e alternativo. "As pessoas que o frequentam são livres de preconceitos. Além de tocar de tudo, gosto especialmente quando começa o Ragatanga do Rouge" (Medeiros, entrevista concedida em 12 de Junho de 2017).

Até 2006, o bar era um pequeno quiosque que vendia a cachaça da casa "Misteriosa do Encanto" e reproduzia ritmos nordestinos (coco, maracatu, ciranda, manguebeat e forró), músicas brasileiras de outros seguimentos, além de ser um espaço de venda de CDs de artistas paraibanos. No ano subsequente, deu-se início às divergências entre o proprietário e a coordenação do evento, pois essa passou a questionar o uso do som e o perfil dos frequentadores do estabelecimento, composto majoritariamente por cabeludos e tatuados com brincos e piercing. Apesar disso, o ano de 2008 foi marcado pela resistência tanto por parte do proprietário quanto por seus frequentadores.

Toda sexta e sábado, a partir da meia noite, era um "mar de gente" em frente ao quiosque de 2 metros quadrados. O proprietário relata sua resistência e afirma: "fomos multados, ameaçados e depois subornados a tirarem a multa em troca de apoio político. Não 
cedi e começou um novo processo, o de criar um bar dentro do Parque do Povo, todo legalizado, e sem dever nada a nenhuma esfera pública" (Carlos, entrevista concedida em 12 de junho de 2017).

Após esse período, de 2009 a 2014, houve a configuração do Palco Multicultural do Tenebra, simultaneamente à programação oficial do Palco Principal e das palhoças, evidenciando o encontro de ritmos regionais ${ }^{12}$ :

Escolhi ficar no local menos movimentado, a coordenação me alertou que lá era complicado para vendas, devido a baixa circulação de pessoas. Mesmo assim pedi para ficar na última barraca do local, para poder ficar na pista e não ter proibição de som, resultado, lotamos a área em 2015 e 2016. Um dos nossos diferenciais para atrair tanto público é fazer com que aquele espaço seja uma zona livre de preconceitos, principalmente dos homofóbicos. Compartilhamos o espaço democraticamente e ficamos atentos aos movimentos preconceituosos, por entender que todos têm o direito de ir e vir e de ser quem são sem interferências da sociedade (Carlos, entrevista concedida em 12 de Maio de 2017).

Em 2017, a determinação foi a de não utilizar sons nas barracas. Ocorrendo a violação dessa normatização, pagar-se-ia uma multa de 100 mil reais. No entanto, o depoente nos afirmou:

Conseguimos com um abaixo assinado e com muito diálogo a liberação. Nossos clientes ajudaram muito. Além de ajudar a conseguir as assinaturas, eles contribuíram para a arrecadação do valor do aluguel do nosso espaço com uma vaquinha online (Carlos, entrevista concedida em 12 de Junho de 2017).

Na Pirâmide, realizou-se o casamento comunitário, shows de trio de forró e apresentações de quadrilhas e grupos folclóricos, com destaque para o concurso de quadrilhas juninas de Campina Grande, ocorrido nos dias 9 e 10 de Junho de 2017.

As quadrilhas trouxeram muito brilho, música ao vivo, cenografias, coreografias e temáticas variadas, desde a fertilidade da terra no Nordeste até as religiões afro-brasileiras. Todavia, antes de começar, a associação teve problemas com a empresa organizadora do evento, conforme o depoimento abaixo:

Estamos vendo uma certa descaracterização do Parque do Povo, estão elitizando uma festa que é do povo, e assim, esse ano ocorreu um grande desrespeito com relação a Pirâmide. Foi uma luta férrea para que a conseguíssemos de volta para as quadrilhas. A Pirâmide é a "casa das quadrilhas" em Campina Grande, é um símbolo para todo o Nordeste e para

\footnotetext{
${ }^{12}$ Sugerimos o vídeo disponível em: https://www.youtube.com/watch?v=Q4gsq6ZScBs, acesso em: 10/09/2017.
} 
todo quadrilheiro. Infelizmente a Aliança não queria permitir que o festival ocorresse lá e os nossos governantes não podiam deixar uma empresa fazer isso com a nossa cultura. O São João é uma festa do povo e para o povo, o Parque do Povo é do povo, o próprio nome já indica, não é justo que nenhuma pessoa ou empresa chegue e queira transformá-lo em uma festa de riquinho, em um open bar ou área prime. Ali é do povo (Marcos, entrevista concedida em 11 de junho de 2017).

Resolvidos os empasses, as quadrilhas voltaram a se apresentar no local de costume. Antes das 19 horas as arquibancadas estavam totalmente repletas de espectadores, muitos vestidos com as camisas de suas festas juninas preferidas e com bolões de ar na cor da sua quadrilha favorita. Acreditamos que se tratem de geossímbolos, definidos por Bonnemaison (2002, p. 109), “como um lugar, um itinerário, uma extensão que, por razões religiosas, políticas ou culturais, aos olhos de certas pessoas e grupos étnicos assume uma dimensão simbólica que os fortalecem em sua identidade", potencializando as disputas entre as principais quadrilhas rivais: Moleka Sem Vergonha e Mistura Gostosa.

Nos bastidores de cada apresentação, notava-se a ansiedade, preocupação e muita emoção. Os participantes das quadrilhas juninas faziam orações e entregavam aquele momento às divindades, por meio de orações pessoais e coletivas (Pai Nosso). Adentrando a Pirâmide, os simpatizantes de cada quadrilha, em grande parte originários do mesmo bairro, exteriorizavam por meio de gritos, músicas e gestos a felicidade em vivenciar o espetáculo. Saindo da Pirâmide, indo em direção à parte inferior, estão as Palhoças ${ }^{13}$ de forró, as quais são mais frequentadas por adultos e idosos, bem como o espaço da Ypióca ${ }^{14}$.

Seguindo pela festa, encontra-se a réplica da Catedral Diocesana Nossa Senhora da Imaculada Conceição, com a exposição das imagens dos santos juninos e de quadros feitos com base em narrativas bíblicas. Na Vila Nova da Rainha, localizam-se os vendedores de artesanato, ao lado dos stands de patrocinadores do evento, com destaque para a Vila Skol ${ }^{15} \mathrm{e}$ a reprodução de música eletrônica.

Quanto mais distante da Pirâmide, maior é o tamanho dos bares, a diversidade de alimentos e o poder aquisitivo de seus frequentadores, em uma localização próxima ao Palco Parafuso, onde ocorrem apresentações de bandas de forró. Todavia, mesmo em meio a esse caráter mercadológico da festa, as pessoas estabelecem vínculos de afetividade com o local,

\footnotetext{
13 Registro videográfico disponível em: https:/www.youtube.com/watch?v=8-eQtUsiV1I, acesso em: 10/09/2017.

14 Registro videográfico disponível em: https://www.youtube.com/watch?v=kg3juQGcnQs, acesso em: $10 / 09 / 2017$.

15 Registro videográfico disponível em: https://www.youtube.com/watch?v=SjhA9V8UYHE, acesso em: $10 / 09 / 2017$.
} 
constroem territorialidades, além de estabelecerem momentos de encontros entre amigos e familiares.

Durante o encerramento da festa, em 2 de Julho de 2017, os impasses e tensões continuaram, muitos barraqueiros e brincantes comentavam sobre o futuro da festa, considerando-se a parceria com a iniciativa privada.

Um mês após o encerramento das festividades, a gestão municipal enviou um projeto de lei para a Câmara de Vereadores autorizando a empresa Aliança a gerir por 20 anos a festividade, a qual deverá no próximo ano (2019), ser transferida do Parque do Povo para o Polo de Eventos Ronaldo Cunha Lima.

\section{Considerações finais}

Buscamos neste artigo apresentar os territórios festivos da cidade de Campina Grande a fim de compreender as apropriações territoriais mediadas pelas práticas sociais e representações subjetivas presentes em sua festa junina. Durante a pesquisa, foi possível deparar-se com apropriações marcadas por tensões, conflitos e sentimentos de pertencimento aos locais festivos. Em meio a festividade para fins turísticos, os territórios festivos dos bairros têm decrescido. Entre várias explicações para isso, pode-se citar as intervenções no espaço urbano que limitam o acendimento de fogueiras, o crescente índice de violência urbana, a ausência de aporte financeiro por parte da Prefeitura Municipal e o desinteresse dos mais jovens.

Os bairros Bela Vista, Bodocongó, Distrito Industrial, Dinamérica, Jardim Quarenta, Nova Brasília e Santo Antônio se afirmam como territórios de resistência em meio a mercantilização vigorante, tendo como principais mediadores a Igreja Católica e as associações de bairros, mediante as celebrações eucarísticas, novenas, quermesses, corrida de jegue, apresentações musicais e de quadrilhas, com amplo uso dos espaços públicos. Em alguns desses locais, a gestão municipal, vereadores e deputados apoiam as comemorações com a disponibilização de sonorização e iluminação, objetivando a conquista de votos no próximo pleito eleitoral, uma vez que os presidentes das associações de bairros possuem liderança na comunidade.

Como vimos, os embates territoriais ocorrem no Parque do Povo antes mesmo de a festa começar. Desde o anúncio da programação oficial do palco principal, esta foi mal vista por alguns dos nossos entrevistados, já que as grandes bandas de forró estilizadas, axé music, 
funk e sertanejo ganham espaço na festa junina. A presença dessas bandas evidencia uma relação estreita com a privatização da festa junina, uma vez que ao financiar uma festa desse porte os patrocinadores esperam um retorno financeiro expressivo. Assim sendo, essas atrações simpatizadas pela grande massa é um "tiro certeiro" a fim de se atingir as metas de vendas.

Como consequência do seu caráter mercadológico, as tensões são reforçadas pela segregação socioespacial e pelas condições socioeconômicas dos sujeitos, as quais ditam onde estes devem permanecer no local festivo. Acrescenta-se a isso as resistências referentes às territorialidades alternativas, com destaque para o público LGBT e para as quadrilhas juninas "estilizadas". Todavia, mesmo em meio a essa lógica de venda da comemoração, os indivíduos mantêm as suas relações de afetividade com as festividades do Parque do Povo.

É inegável a concentração, espetacularização e hegemonia das festas juninas oficiais em Campina Grande, que acabam comprometendo a espontaneidade de algumas festas juninas de bairro. Todavia, estas coexistem e continuam em um constante processo de reinvenção, evidenciada por tensões nos territórios festivos juninos de Campina Grande, tanto do ponto de vista material quanto simbólico.

\section{Referências Bibliográficas}

ALBUQUERQUE JÚNIOR, D. M de. A feira dos mitos: A fabricação do folclore e da cultura popular (Nordeste 1920-1950). São Paulo: Intermeios, 2013.

ÁLVAREZ, C. A. M. Metodología de la investigación cuantitativa y cualitativa: Guia didáctica. Universidad Surcolombiana, Neiva, 2011.

BEZERRA, A. C. A (re) invenção das Festas e da Identidade no espaço urbano de Mossoró - RN. Tese (Doutorado em Geografia) - Centro de Estudos Gerais, Instituto de Geociências da Universidade Federal Fluminense, Niterói- Rio de Janeiro. 2006.

BONJARDIM, S. G.M; ALMEIDA, M. G de. Templos rituais como patrimônio cultural: A geografia nas Análises da Religião. In.: VARGAS, M. A.M; DOURADO, A. M; SANTOS, R. H dos. (Orgs.). Práticas e vivências com a Geografia Cultural. Aracaju: Editora Diário Oficial do Estado de Sergipe - Edise, 2015.

BONNEMAISON, J. Viagem em Torno do Território. In: CORRÊA, R. L; ROSENDAHL, Z (Orgs.). Geografia Cultural: Um século. Rio de Janeiro: EdUERJ, 2002.

CASTRO, J. R. B de. Da casa à praça pública: a espetacularização das festas juninas no urbano. Salvador: EDUFBA, 2012.

CHIANCA, L. São João na Cidade: ensaios e improvisos sobre as festas juninas. João Pessoa: Editora da UFPB, 2013.

CLAVAL, P. Geografia Cultural: o estado da arte. In: CORRÊA, R. L.; ROSENDHAL, Z. (Org.) Manifestações da cultura no espaço. Rio de Janeiro: EDUERJ, 1999, p. 59-97.

CORRÊA, R. L. Olhares Geográficos: Modos de ver e viver e espaço. Rio de Janeiro: Bertrand Brasil, 2012. 
CORRÊA, M de V; ROZADOS, H. B. F. A netnográfia como método de pesquisa em Ciência da Informação. In.: Revista eletrônica de biblioteconomia e ciência da informação, n.49, v. 22, Maio/Ago, 2017, p. 1-18.

DEL PRIORE, M. L. Festa e utopias no Brasil colonial. São Paulo: Brasiliense, 2000.

DOZENA, A. As territorialidades do Samba em São Paulo. Tese (Doutorado em Geografia). Programa de Pós-Graduação em Geografia Humana, Universidade de São Paulo. São Paulo, 2009.

Territorializações Urbanas Como Práticas de Resistência. Terra Plural, Ponta Grossa, n.2, v.6, 2012, p. 215-228.

EUlÁLIO, M. D. Bate coxa em Campina Grande: História social do forró na cidade do "Maior São João do Mundo" (1950-1985). Dissertação (Mestrado em História) Universidade Federal de Campina Grande, 2014.

FERNANDES, N da N. Geografia Cultural, festa e cultura popular: limites do passado e possibilidades do presente. Espaço e Cultura, Rio de Janeiro, n. 15, Jan./ Jun. 2003, p. 23-43. GOMES, P. C da C. O lugar do olhar: elementos para uma geografa da visibilidade. Rio de Janeiro: Bertrand Brasil, 2012.

GRAVARI-BARBAS, M. Novas festas, novos lugares, novas espacialidade. Para uma geografia dos eventos festivos em Paris. Revista Cidades. Presidente Prudente - SP, 2011, p. 207-228.

GWIAZDZINSKI, L. A cidade por intermitência: Do tempo da festa a um urbanismo dos tempos. Revista Cidades. Presidente Prudente - SP, 2011, p. 337-357.

HAESBAERT, R. Da. Viver no Limite: território e multi/transterritorialidade em tempos de in-segurança e contenção. Rio de Janeiro: Bertrand Brasil, 2014.

HEIDRICH, Á. L. Método e metodologias na pesquisa das geografias com cultura e sociedade. In.: HEIDRICH, Á. L; PIRES, C. L. Z. (Orgs.). Abordagens e práticas da pesquisa qualitativa em geografia e saberes sobre espaço e cultura. Porto Alegre: Editora Letra1, 2016.

KIM, K. Os dois valores utilizados hoje pelas festas tradicionais em duas localidades coreanas. Revista Cidades. Presidente Prudente - SP, 2011, p. 163-180.

LIMA, E. C. A. A fábrica dos Sonhos: a invenção da festa junina no espaço urbano. $2^{\mathrm{a}}$ Ed. Campina Grande, EDUFCG, 2008.

LIMA, S. C de. Os que já estavam: A perspectiva existencial de sujeitos indígenas em Góias. In.: CHAVEIRO, A. F; CASTORINO, A. B; BORGES, R. M. R. (Orgs.). Espaço, sujeito e existência. Goiânia: Ed. Da PUC Goiás, 2016.

MADOEUF, A. Uma semana da vida de uma cidade: Sobre os mûlds do Cairo. Revista Cidades. Presidente Prudente - SP, 2011, p. 305-315.

MARQUES, J.A.S. As territorialidades da Festa Junina de Campina Grande - PB (2016 2017). Dissertação (Mestrado em Geografia) - Universidade Federal do Rio Grande do Norte, 2018.

MARQUES, L. M; BRANDÃO, C. R. As festas populares como objeto de estudo: contribuições geográficas a partir de uma análise escalar. Ateliê Geográfico, Goiânia - GO, n.3, v. 9, p. 7-26, Dez. 2015.

MELO, E. M. A paisagem em foco: leituras fotográficas de Jardim do Seridó-RN. Dissertação (Mestrado). Universidade Federal do Rio Grande do Norte. Natal- RN, 2008.

MORIGI, V. J. Narrativas do Encantamento: O maior são João do mundo, média e cultura regional. Porto Alegre: Armazém digital, 2007.

PAULA, F. C de. Sobre a Dimensão Vivida do Território: tendências e a contribuição da Fenomenologia. Geotextos, v. 7, p. 105-126, 2011. 
SANGUIN, A. Fim da Geografia ou Vinganças da Geografia? As sociedades entre um mundo liso, um mundo pontudo ou um mundo plano. In.: Revista Franco-Brasileira de Geografia, n. 22, 2014.

Recebido em 10 de setembro de 2018.

Aceito em 03 de outubro de 2018. 